\title{
QUALITY ASSESSMENT SYSTEM FOR TEACHING ACTIVITIES
}

\author{
SISTEMA DE EVALUACIÓN DE CALIDAD PARA \\ ACTIVIDADES DOCENTES
}

\author{
Galina V. Petruk \\ ${ }^{1}$ Candidate of Pedagogic Sciences (PhD in Pedagogy), Associate Professor, \\ Department of Management, Vladivostok State University of Economics and \\ Service, 41 Gogol Street, Vladivostok, 690014, Russia, E-mail:
}

Enviado: 27 de junio de 2019

Galina.Petruk@vvsu.ru

Aceptado para publicar: 30 de julio de 2019

Publicado: 8 de agosto de 2019

\begin{abstract}
The specialist training quality in the higher education system directly depends on the effectiveness of the teaching staff in universities. This paper presents the methodological aspects of assessing the quality of teaching activities in universities. The quality assessment of teachers' work should be based on the quality of educational services they provide, which can be measured from two points of view: the compliance of the achieved educational results with accepted state standards and their compliance with the demands of consumers (students). One of the most important modern approaches to personnel assessment is the competency-based approach, which allows us to give the most objective picture of the professionally important qualities of employees. The paper analyzes the main methods of assessment of the teaching staff and highlights the assessment criteria. It is proposed to use a number of principles in order to ensure the effectiveness of the teacher assessment system. In practice, the quality assessment of the teaching activities should be a system, the totality of the elements of which makes it possible to reliably identify the potential of teachers and provide quality training for future specialists in a higher educational institution.
\end{abstract}

Keywords: quality of education, quality assessment methods, quality assessment of the teachers' work, competency-based approach.

La calidad de la formación especializada en el sistema de educación superior depende directamente de la efectividad del personal docente en las universidades. Este artículo presenta los aspectos metodológicos de la evaluación de la calidad de las actividades de enseñanza en las universidades. La evaluación de la calidad del trabajo de los docentes debe basarse en la calidad de los servicios educativos que brindan, que se puede medir desde dos puntos de vista: el cumplimiento de los resultados educativos alcanzados con los estándares estatales aceptados y su cumplimiento con las demandas de los consumidores (estudiantes ) Uno de los enfoques modernos más importantes para la evaluación del personal es el enfoque basado en competencias, que nos permite dar la imagen más objetiva de las cualidades profesionalmente importantes de los empleados. El documento analiza los principales métodos de evaluación del personal docente y destaca los criterios de evaluación. Se propone utilizar una serie de principios para garantizar la efectividad del sistema de evaluación docente. En la práctica, la evaluación de la calidad de las actividades docentes debe ser un sistema, cuya totalidad de los elementos permita identificar de manera confiable el potencial de los docentes y proporcionar capacitación de calidad para futuros especialistas en una institución de educación superior.

Palabras clave: calidad de la educación, métodos de evaluación de la calidad, evaluación de la calidad del trabajo de los docentes, enfoque basado en competencias. 


\section{Introduction}

Education is becoming the most important factor in ensuring the competitiveness of the national economy. The main issue in the preparation of future specialists comes to the quality of educational services, and it cannot be solved only by super-modern technical means. Now the technical equipment of various universities is practically the same. The quality of education depends on which university a student graduates from, and the image of an educational institution is determined primarily by the level of the teaching staff involved in the educational process. The efficiency and effectiveness of university activities is an indicator of the well-coordinated work of the teaching personnel, the presence of highly professional staff that directly affect the quality of training future specialists.

Problems of improving the quality of education make university management pay considerable attention to human resources, especially to those who constitute them. Therefore, the assessment of professionally important qualities, competencies, and the performance of the work by university teachers, as an essential element of education quality management, is of particular importance. Thus, improving the performance assessment of the teaching staff in universities is a complex and relevant task for modern management.

\section{Theoretical and methodological aspect of the problem under study}

A significant contribution to the development of scientific and methodological aspects in the assessment of the quality of teaching staff activity in higher education institutions was made by such scientists as G. A. Bordovsky, N. V. Bordovsky, V. P. Mizintsev, E. V. Titova, S. Yu. Trapitsyn, V.N. Novakov, V.N. Nuzhdin, etc.

Studies reflecting the use of mathematical statistics in assessing the quality of education were carried out by D. Glass, V. Katchalov, D. Stanley, M. Kaplan, and B. Prudkovsky.

The issues of education quality management, both from the standpoint of the general theory of management and based on the introduction of innovative teaching methods, were covered in studies by D. Tatyanchenko, S. Vorovshchikov, E. Voutilainen, P. Tretyakov, M. Potashnik, V. Cherkasov, etc.

Despite the enormous interest to the issue, many problems on an assessment of the teachers' work effectiveness in the theory and practice of personnel management remain unresolved. This is influenced by a number of factors such as:

- The specificity of pedagogical work in a higher educational institution, when scientific activity should be combined with pedagogical and educational ones,

- Features of labour relations,

- The adequacy of the choice of certain personnel assessment methods.

These features determine the relevance of research in the use of methods for assessing the quality indicators of teachers.

The purpose of this study is to develop the methodological aspects of assessing the quality of university teaching staff.

To achieve the goal and solve the problems formulated, the following general scientific research methods were used: analysis and synthesis, grouping, comparison, induction and deduction methods, etc.

\section{Results and their Discussion}

The assessment of employees is understood to be the identification of their personal behavioural and professional characteristics, which are a specific expression of staff compliance with the requirements for the position or workplace, according to which a manager evaluates the effectiveness of their work [1]. The main purpose of the assessment is to determine the level of qualifications of employees and to identify with them certain abilities, skills, competencies, etc., which the leadership of the organization are interested in,

The system for assessing the quality of teachers' activity is an orderly and integral set of elements, the interaction between which makes it possible to reliably reveal the potential of teachers to provide quality training for future specialists in a higher educational institution.

Thus, the quality assessment system should include a number of the following elements:

- Personnel assessment methodology;

- Quality assessment procedure;

- Quality assessment criteria.

It must be emphasized that the basis for assessing the quality of teachers should be based on the assessment of the quality of the educational services they provide, and it can be measured from two perspectives:

- Compliance of the achieved educational results with the accepted state standards;

- Their compliance with the needs of consumers (students). In modern scientific research, the quality of education and human development is considered as an integral characteristic [2], as well as from system-structural positions, which presupposes the selection of defining properties in the context of their most significant external and internal relations $[3,21]$. At the same time, the quality of educational results should be distinguished from the quality of the educational process and the quality of the educational system. To determine the compliance of the real quality of 
education with the standard adopted, E.V. Yakovlev [4] suggests using the following simplified formula:

Quality of education $=$ properties of the actual result

essential properties of the desired result

The properties of an actual result directly depend on the performance quality of teachers, including their qualifications, methodical work, etc. In practice, two criteria for personnel assessment are usually distinguished: they are an assessment of competences, which makes it possible to judge the knowledge, skills, competencies, personal qualities of employees, and an assessment of performance, which allows us to compare the planned results that employees needed to achieve with those performed [5].

One of the important modern approaches to personnel assessment is the competency-based approach, which allows us to give the most objective picture of the professionally important qualities of workers $[6,7,18]$. A competency is a set of interrelated skills, abilities and knowledge, providing an effective solution by an employee of a certain volume of tasks. It is advisable to build a qualitative assessment of the teaching staff based on the competence-based approach. Proceeding from the specifics of the pedagogical activity of teachers, it is necessary to identify assessment criteria, which are based on the structural components of the professional competence of a university teacher.

There are four groups of criteria:

- Research and innovation;

- Educational and pedagogical; competence;

- Educational and methodical; competence;

- Career guidance.

Each of the criteria can be divided into a number of indicators that have different significance.

Personnel assessment is carried out by certain methods, which are quite a lot in this practice of personnel management [8-10, 19]. Personnel assessment methods can be divided into three groups: qualitative, quantitative and combined.

Qualitative personnel assessment methods are more descriptive because they have no quantitative restrictions, for example, "360-degree method", matrix method, the system method, group discussion method, task performance analysis, system of arbitrary characteristics. In quantitative methods, assessment results are expressed in numbers. When using them, it is just enough to compare employees by the given parameters. These methods include the ranking one, when a manager makes a rating of employees, the scoring method when each achievement of personnel is estimated by a certain number of points, which are summarized by the end of the period, etc. The most effective assessment methods are combined, which use both descriptive and quantitative assessments and also allow an employee to be evaluated from all sides. These include: testing (solving tests and professional tasks), the test score method (assessment a person's characteristics on a certain scale, an average is derived, which is then compared to an ideal one) and a grouping system when all employees are divided into groups according to their efficiency (effective and not effective).

Despite the variety of methods used for assessing teaching staff members [11-17] in the practice of Russian universities, the main goal of the procedure used remains to determine whether the quality of the teacher's work in classes complies with modern education transformation requirements.

Table 1. Characteristics of common qualitative methods for the assessment of teaching staff in universities

\begin{tabular}{|c|c|c|}
\hline Method & $\begin{array}{l}\text { Characteristics } \\
\text { of the method }\end{array}$ & $\begin{array}{l}\text { Features of the } \\
\text { method }\end{array}$ \\
\hline $\begin{array}{l}\text { 360-degree } \\
\text { method }\end{array}$ & $\begin{array}{l}\text { Assessment of } \\
\text { an employee } \\
\text { from all sides } \\
\text { (colleagues, } \\
\text { students, } \\
\text { supervisor, etc.) }\end{array}$ & $\begin{array}{l}\text { Makes it } \\
\text { possible to get } \\
\text { an objective } \\
\text { comprehensive } \\
\text { result. Can be } \\
\text { used as a } \\
\text { feedback tool. }\end{array}$ \\
\hline Rating & $\begin{array}{l}\text { Assessment by } \\
\text { the performance } \\
\text { of the functions } \\
\text { or teachers' } \\
\text { work results. } \\
\text { Based on the } \\
\text { assessment of } \\
\text { an employee's } \\
\text { compliance with } \\
\text { the position } \\
\text { held. }\end{array}$ & $\begin{array}{l}\text { Does not cover } \\
\text { the whole } \\
\text { spectrum of the } \\
\text { teacher's } \\
\text { activities. }\end{array}$ \\
\hline Matrix & $\begin{array}{l}\text { Involves } \\
\text { comparing the } \\
\text { qualities of a } \\
\text { particular } \\
\text { person with the } \\
\text { ideal } \\
\text { characteristics } \\
\text { for the position } \\
\text { held }\end{array}$ & $\begin{array}{l}\text { Common } \\
\text { methods; } \\
\text { employee } \\
\text { functionality is } \\
\text { used as the } \\
\text { comparison } \\
\text { criterion. }\end{array}$ \\
\hline Interview & $\begin{array}{l}\text { Dialogue } \\
\text { between the } \\
\text { objects of study } \\
\text { with the head } \\
\text { and members of } \\
\text { the personnel } \\
\text { commission in } \\
\text { the field of } \\
\text { work on the } \\
\text { results of their } \\
\text { work and }\end{array}$ & $\begin{array}{l}\text { A subjective } \\
\text { approach is } \\
\text { possible }\end{array}$ \\
\hline
\end{tabular}




\begin{tabular}{|l|l|l|}
\hline & prospects & \\
\hline $\begin{array}{l}\text { Certification } \\
\text { of theaching } \\
\text { staff }\end{array}$ & $\begin{array}{l}\text { The distance } \\
\text { professional the } \\
\text { level } \\
\text { compliance } \\
\text { assessment } \\
\text { method for the } \\
\text { staff; it is } \\
\text { provided for by } \\
\text { the labour } \\
\text { legislation of } \\
\text { the Russian } \\
\text { assessment } \\
\text { procedure. }\end{array}$ \\
\hline $\begin{array}{l}\text { Federation and the } \\
\text { Analysis }\end{array}$ & $\begin{array}{l}\text { Interpretation of } \\
\text { the information } \\
\text { contained in the } \\
\text { documents }\end{array}$ & $\begin{array}{l}\text { Formal } \\
\text { assessment } \\
\text { method which } \\
\text { bears } \\
\text { subjectivism. }\end{array}$ \\
\hline
\end{tabular}

As mentioned above, a quality assessment of the teaching staff activity at universities is always aimed at objectively identifying the correspondence between the existing and the required levels of professionalism.

Diagnostic tools for determining the effectiveness of the system for assessing the quality of the teaching staff's activities should not be cumbersome and require a large amount of time and effort to prepare, conduct, review and process the results obtained. Such tools can be:

- A test for students, since they are the main consumers of educational services and it is necessary to know their level of satisfaction with the result, process and quality of their education;

- Analysis of lesson attendance, which gives information to an expert for a possibility to determine the level of professionalism, pedagogical skills, and the ability to apply modern teaching methods by a teacher;

- Analysis and assessment of the individual rating results, which takes into account the qualitative results of the teacher's activities. The set of indicators that may be included in the rating system depends on the choice of strategic directions of the university management. For example, such indicators may include the level of application of the electronic educational environment, the results of students in scientific and educational events of different levels, preparing students for participation in WorldSkills, the results of scientific research reflected in foreign and domestic scientometric databases, as well as the implementation of scientific projects;

- Self-assessment sheet for teachers where they can indicate what is not included in the above indicators.

The subjects of assessment can be teachers, colleagues, direct manager (head of the department), and personnel committee. It should be noted that in the practice of Russian universities, in contrast to foreign ones, it is not common to identify student grades for a teacher, despite the fact that students are the main consumers of educational services [10,20].

In order to ensure the effectiveness of the teacher assessment system, it is necessary to adhere to a number of the following principles:

- The systematicity (or repeatability) principle. Due to the fact that the educational environment is changing dynamically, the requirements for the training of specialists and for the use of modern educational technologies in the training process, etc. change. It is necessary to conduct a regular assessment of staff. The optimal repeatability period for the personnel quality assessment is 1 time in three years;

- The impartiality and objectivity principle which is based on a scientific approach, impartiality, and open-mindedness of experts;

- The confidentiality principle ensures that information on the assessment results will be used only by a limited number of persons and for inhouse conclusions made by the university management;

- The principle of competence. The subject who makes assessments must be a professional in personnel assessment, must understand the modern requirements for the educational process, he must understand modern educational technologies, and the specifics of the teacher work in universities;

- The principle of individuality, proceeding from the position that each teacher value of the organization and each has its own results.

\section{Conclusion}

Requirements for the training of modern specialists are constantly being tightened. And the main reason is the demands of the time. Today, students during their studies must master not only a sound basic, i.e. fundamental education, but must also acquire knowledge, which in the future will enable them to improve this competencies and abilities for self-education. And only those teachers who own modern pedagogical technologies, who are able to self-educate themselves and increase their own competencies, can accomplish this task.

Thus, in the logic of continuous changes occurring in the educational environment, a teacher must not only have professional competencies that ensure the effectiveness of his/her activities, and also the activities of the entire higher education institution, but also strive to improve the quality of training specialists.

Effective using of the methodology aspects for assessing higher education teachers presented in the paper requires the fulfillment of a number of conditions: building an assessment system based 
on certain principles, development of indicators for each criterion; engagement of not only the immediate supervisors, but also students and colleagues to obtain an objective assessment of the teaching staff's performance. The theoretical and practical significance of the presented results lies in the development of specific measures aimed at improving the teacher assessment system management through the introduction of the developed methodology into practice.

\section{References}

1. Trapitsyn S.Yu., Vassilyeva E.Yu. The quality assessment system for the university teachers activity as a subject of research and design object: https://cyberleninka.ru/paper/n/sistemaotsenki-kachestva-deyatelnostiprepodavateley-vuza-kak-predmetissledovaniya-i-obekt-proektirovaniya

2. Polonsky V.M. Scientific and pedagogical information: reference dictionary. - M.: Novaya Shkola, 1995. $256 \mathrm{p}$.

3. Panasyuk V.P. Pedagogical system of intraschool educational process quality management: thesis for the degree of Doctor of Pedagogical Sciences. - SPb, 1998. - 460 p.

4. Yakovlev E.V. Intra-university education quality management: Monograph. Chelyabinsk: Publisher ChGPU, 2002. $390 \mathrm{p}$

5. Reznik S.D. Teachers of Russian universities: the formation and development of professional competencies / S.D. Reznik, O.A. Vdovina. - M.: INFRA-M, 2016. - 139 p.

6. Isaeva T.E., Churikov M.P., Kotlyarenko $\mathrm{Y}$. Yu. The efficiency of assessment the activities of university teachers: a comparison of domestic and foreign methods /! Internet magazine "Naukovedenie" Volume 7, No. 3 (2015) http://naukovedenie.ru/PDF/141PVN315 .pdf (free access). Title from the screen. Languages - Russian, English. DOI: 10.15862 / 141PVN315

7. Andreev A. L. Competence paradigm in education: the experience of philosophical and methodological analysis / A.L. Andreev // Pedagogy. 2005.- №4. - p.19-26

8. Ilyina M.A., Kopylova N.T., Polovnikova E.S. Criteria for quality assessment of teacher's work. URL: http://elib.altstu.ru/elib/disser/conferenc/ 2010/01/pdf/306ilyina.pdf.

9. E.A. Mogilevkin , O.V. Gorshkova , A.S. Novgorodov. Appraisal of staff in high school: analysis, opportunities, prospects // University Management. 2008 No. 1. Pp. 48-54.

10. Petruk G.V., Shashlo N.V., Kleshcheva N.A., Vlasenko A.A., Stasenko I.N. The industrial-educational cluster environment as a tool of the staff capacity forming of the Russian onecompany towns // International Journal of Humanities and Cultural Studies. 2016. № S1. P. 788-799.

11. Petruk G.V., Lebedinskaya Y.S., Kleshcheva N̈.A., Korostelev A.A. Internationalization of higher education of China as the factor of university competitiveness increase // Revista San Gregorio. 2018. Vol. 25. P. 178-185

12. Vasilyeva E.Yu. Approaches to quality assessment of a university teacher's activity // University Management: Practice and Analysis. 2006. - № 2. Pp. 74-78.

13. Bordovskaya N.V. Methodology for quality, assessment of university teacher's activities: Methodical E.V. Titova. SPb.; Arkhangelsk, 2003. $72 \mathrm{p}$.

14. Vasilyeva E.Yu. Assessment of the teachers' activities in Russian and foreign universities: Monograph. University, 2005. - $170 \mathrm{p}$.

15. Ceisil, U. (2018). E-Awareness of University Student through Smart Phones and Developing Social Networks. Journal of Humanities Insights, 02(03), 139-145. doi:10.22034/JHI.2018.70850

16. Kashisaz, S., \& Mobarak, E. (2018). The Effects of Private Education Institutes in Providing Modern Financial Knowledge in Developing Countries. Journal of Humanities Insights, 02(04), 172-178. doi:10.22034/JHP.2018.80887

17. Kumar, S., \& Gapta, V. (2017). Advantages and Disadvantages of Social Websites on Young Students. Journal of Humanities Insights, 01(01), 34-36. doi:10.22034/JHI.2017.59561

18. Muhammad, K. (2018). The Effects of Electronic Human Resource Management on Financial Institutes. Journal of Humanities Insights, 02(01), 01-05. doi:10.22034/JHI.2018.61036

19. Upikang, B. (2017). Summative Evaluation of Teacher Performance by Secondary School Students. Journal of Humanities Insights, 01(02), 63-75. doi:10.22034/JHI.2017.59565

20. Ajallooeian, E., Gorji, Y., \& Niknejadi, F. (2015). Evaluate the Effectiveness of Social Skills Training through Group Therapy Play on Reducing Rational Aggression Boy Elementary School Student in Esfahan City. UCT Journal of Social Sciences and Humanities Research, 3(1), 1-4.

21. Shukla, S. (2017). INNOVATION AND ECONOMIC GROWTH: A CASE OF INDIA. Humanities \& Social Sciences Reviews, 5(2), 64-70. https://doi.org/10.18510/hssr.2017.521 